\title{
INSTILLING CHARACTER VALUE OF COOPERATION THROUGH TRADITIONAL GAME IN SD NEGERI MEJASEM BARAT 03 TEGAL REGENCY
}

\author{
Akhmad Junaedi ${ }^{*}$, Tri Astuti ${ }^{2}$ \\ Universitas Negeri Semarang, INDONESIA
}

Received 11 May 2021 - Revised 30 August 2021 - Accepted 20 September 2021

\begin{abstract}
Traditional games are one of the wealth of the Indonesian nation that must be preserved. Conservation efforts can be implemented in schools. The main target is elementary school students because they have no difficulty getting to know the culture at this age. Traditional games can also be used to instil the character value of cooperation in groups. This value is beneficial for them in facing global challenges in society. The research method is qualitative because the data to be obtained is in the form of words and sentences from the object of research. This data describes how students show a cooperative attitude at school. This collaboration will be seen after the researcher introduces traditional games to students. They will then practice it with their classmates. Data were collected using observation, interview, questionnaire and documentation. The validity of the data was checked by triangulation of sources and methods. The process of instilling the character value of cooperation in elementary students through traditional games experienced certain obstacles, but these obstacles could be overcome by collaborating with various parties such as students, parents and teachers.
\end{abstract}

Keywords: Character Value of Cooperation, Traditional Game

\section{INTRODUCTION}

Geographically, SD Negeri 03 Mejasem Barat, Tegal Regency, is located on the city and district borders. This affects the relation and behaviour of students. Their lives are more influenced by urban elements, where life in cities tends to be more materialistic, individualistic and has low social sensitivity. This trait needs to be removed slowly so that students have a social spirit. It is not an easy thing to implement and change student behaviour and it takes a relatively long time. Besides, students need innovative ways so that they are interested in learning while playing. In this case, learning is the implementation of character education in schools by teachers. Education seeks to transform cultural values to achieve both individual and community progress. Position and function of education as a center of cultural development, study centers, and the development of sciences for the progress of human civilization [1].

The Ministry of Education and Culture (2010: 9-10) states that character education in Indonesia is based on eighteen noble values as the foundation for national character, namely: 1) religiosity, 2) honesty, 3) tolerance, 4) discipline, 5) hard work, 6) creative, 7) independent, 8) democratic, 9) curiosity, 10) spirit of nationality, 11) love the country, 12) rewarding achievement, 13) friendly/communicative, 14) peace-loving, 15) fond of reading, 16) care for the environment, 17) social care, 18) responsibility. These values are the manifestation of the five main values of character which are interrelated, namely religiosity, nationalism, independence, cooperation and integrity that are integrated into the curriculum (Permendikbud, No. 20 the year of 2018, article 2 paragraph 2). This value is translated into several character values. Social care is the ability to have a socially sensitive spirit, cooperation and mutual respect.

The government expects students to progressively change through the school. Students should not only smart but also have good moral and can preserve Indonesian culture. The rapid development of technology, of course, has a positive and negative impact on children. They are getting smarter in finding any information about world life, but sometimes they forget the national culture that needs to be preserved in life. Indonesian culture is a society's wealth that must not fade or disappear because of national identity. Every citizen must uphold it, even though many foreign cultures have entered this country. It is not always right that foreign culture is good and Indonesian culture is bad. It is relative, depending on the human's point of view. In today's society, many cases should not be committed by elementary school children, for example, fights between students, bullies and even free sex. These cases are influenced by media factors. They do what they watch on TV or the internet. Every day they have free access to anything through their gadgets and they spend less time leaving the house to play with their friends. 
The value of the character of cooperation is very important to be instilled in students of SD Negeri Mejasem 03 so that they have the knowledge and can apply these values in their daily life. Children at elementary school age are in a very decisive stage, where all abilities, both social and emotional, develop [2]. This development must be monitored and accompanied by the teacher. Students will find it difficult if they have to walk alone in the development process. This process requires supports of various parties, including family, teachers and the social environment. All of these components must work together to achieve the desired goals.

In the modern era, innovation is needed to foster students' collaboration abilities, without losing their ancestral heritage. One of the things that can be done is to introduce traditional games. This recognition is not only at the knowledge stage, but also at the stage of practising the values contained in these traditional games. Some of the values contained include the value of cooperation, sportsmanship and social care.

Cultivating or instilling character values can be done through several strategies, including routine school activities, spontaneous activities, modelling, teaching and strengthening the school environment [3]. Schools through teachers must make every effort so that the inculcation of character values in students is successful and achieves goals. This goal is difficult to achieve because the content of the subjects in the elementary school curriculum is very dense so that teachers have limited time to instil student character. The researchers identified major concerns of teachers regarding the teaching of character development that is lack of class time which is a major factor deterring teachers from teaching character development [4].

\section{MATERIAL AND METHOD}

This research uses a qualitative approach. According to Satori \& Komariah, qualitative research is a research approach that reveals social situations by describing reality correctly, formed by words based on relevant data collection and analysis techniques obtained from natural situations [5]. The natural situation is shown by the subjects studied. The research subjects were students of SD Negeri 03 Mejasem Barat Kramat District, Tegal Regency. The informants of this research include teachers, principals and grade 05 students. Informants are people who have information about the events to be investigated by the researcher. Informants are used so that researchers can observe certain events or behaviours. Informants have an important position in qualitative research because they will provide a lot of data that contains information that becomes social facts in schools.

Sugiyono suggests that sampling in a qualitative approach can be done purposively (according to needs) and snowball [6]. When the data is saturated, the observation is stopped. The number of samples is also not determined. Researchers continue to interview when data is still insufficient. Interviews are conducted at school, during formal and non-formal activities. This is done so that the information obtained is more valid. Valid information is very helpful for researchers in answering the problems that arise in this study. If the researcher conducts only formal interviews, students will feel that they are in a tense activity, so a relaxed atmosphere needs to be created during observation and interviews.

Researchers already have a certain way if one day there are students who find it difficult to provide information related to this research. Researchers will take a personal approach so that informants are not afraid of the questions given. Usually, students provide information that is okay because they are afraid of being blamed by their friends or afraid that the statement will affect their grades in class.

The research location is SD Negeri Mejasem Barat 03 Kramat district, Tegal regency. The reason for choosing this location was because the students at the SD were still not able to cooperate with their peers in class. This elementary school is also located on the border of the City and Regency of Tegal so that students also do not understand traditional games. They prefer to play games on cellphones and laptops after school. The school has not provided knowledge about traditional games and how to play them and what are the benefits for students. A research focus is needed so that research is not too broad and complex. This is done so that the research results are more indepth and valid. The focus of this study was (a) the process of instilling the character value of cooperation on the students through traditional games and (b) barriers exist during instilling character values of cooperation on the students.

According to Lofland in Moleong, the main data sources in qualitative research are words and actions; the rest is additional data such as documents [7]. Sources of research data are needed in a certain observation so that the data obtained is more valid and can be trusted by various groups. The source of the data required is from a trusted party. Data sources include primary data sources, namely subjects and informants. In this study, the research subjects were all students of SD Negeri Mejasem Barat 03 Kramat District, Tegal Regency. Some of these students who were considered representative were taken for in-depth interviews. Researchers will focus on grade 05 students. The selection of informants in grade 05 students is carried out using random techniques, where everyone has the same opportunity to become informants. In this case, to strengthen the data, additional informants, namely teachers and school principals, were used. This is used so that the data is more abundant and in-depth so that the results are also valid. Secondary data sources include books or references relevant to the research theme. This written literature source is used as a complement of the source of data from informants.

This written data source includes studies on the value of the character of cooperation. This comes from scientific

(C) 2021 by the authors; licensee PGSD UMP. This article is an open access article distributed under the terms and conditions of the Creative Commons Attribution License (http://creativecommons.org/licenses/by/4.0/). \akhmadjunaedi143@mail.unnes.ac.id @triastuti@mail.unnes.ac.id (*Correspondence) 
research reports, theses, dissertations, journals and literature books that match the topic. In this research, selfgenerated photos were also used during the observation and interview process. The resulting photos are in the form of activities or activities carried out by students in class and the school environment. Moreover, this study also uses documents that support the research. These documents include the number of students, student biodata and so on. Researchers also use a questionnaire to complement the research data.

Data collection was carried out through interview, observation and documentation techniques. The first technique, interview, is a data collection technique used to obtain information directly by uncovering questions to informants. Moleong defines an interview as a conversation with a specific purpose carried out by two parties, namely the interviewer who asks the question and the resource person who provides the answer to the question [7].

Interviews are used to find data to be more in-depth. Researchers interview students first. Then to complete the data, interviews will be carried out with teachers and the headmaster. This interview was also conducted formally and informally so that the data obtained was valid. This is done so that the informant can convey what the researcher needs in a relaxed atmosphere. The second technique, observation, is carried out to see events at school, for example, how students get along with their friends at school, are they able to work together in certain matters. This collaboration, for example, is shown when they are working on group assignments, playing during recess and extracurricular activities. In the process of the third technique, documentation, the documents needed are pictures when they are interacting with their friends in the classroom, school canteen or school library. Researchers will take this data at the time of observation, both in class and outside the classroom. Through pictures and photos, it can be seen their interactions so that the researcher can know their social relationship.

Data validity is very important. To ensure the validity of the data in qualitative research, it is necessary to use triangulation techniques. The triangulation technique used in this study was source triangulation and method triangulation. Researchers obtained the main data from students, then confirmed the data with other sources, namely teachers and the headmaster. Researchers also confirmed the data obtained through observation techniques with data obtained through interview techniques. Data analysis techniques used Interactive Model Data Analysis from Miles \& Huberman which includes [8]1) data reduction, ie. the selection process, focusing on simplifying, abstracting, and transforming "rough" data that emerged from various written notes in the field; 2) presentation of data or information to provide the possibility of taking action; 3) conclusions which are drawn based on the data that has been collected.

\section{RESULTS AND DISCUSSION}

\section{The Process of Instilling Character Value of Cooperation Through Traditional Game}

Character building in Indonesia needs to be handled seriously due to globalization era influences. This condition demands that Indonesia adapt selectively without losing its national identity with its Pancasila ideology [9]. The game used to instil the value of the character of cooperation in students is Gopag Sodor. This game originates from the island of Java, which means gobag (moving) and sodor (spear). This game is one of Indonesia's cultural heritage that must be preserved by the younger generation, starting with children. They can play in groups of 4-5 people in a team. The number of teams is adjusted to the number of children, for example, 30 students of a class can be made into 6 teams consisting of 5 members in each team. The strength of each team must be balanced. Boys and girls are combined evenly. This is also done so that students do not differentiate friends based on gender. Making friends with the opposite sex is important, as long as there are rules to enforce. Critical thinking is necessary for students to identify virtues and reason with their morals. Critical thinking then becomes one of the prerequisites for character education to successfully take place [10].

This process is divided into 4 stages, namely (1) preparation or making the field, (2) general explanation of the rules of the game, (3) playing the game and (4) the stage of giving rewards to the winning and sportive cooperation team. These stages must be carried out so that the activities can be carried out properly. Besides, students must also be ensured that they are in good health. The following is a picture of the preparation for making the Gopag Sodor field at school. 


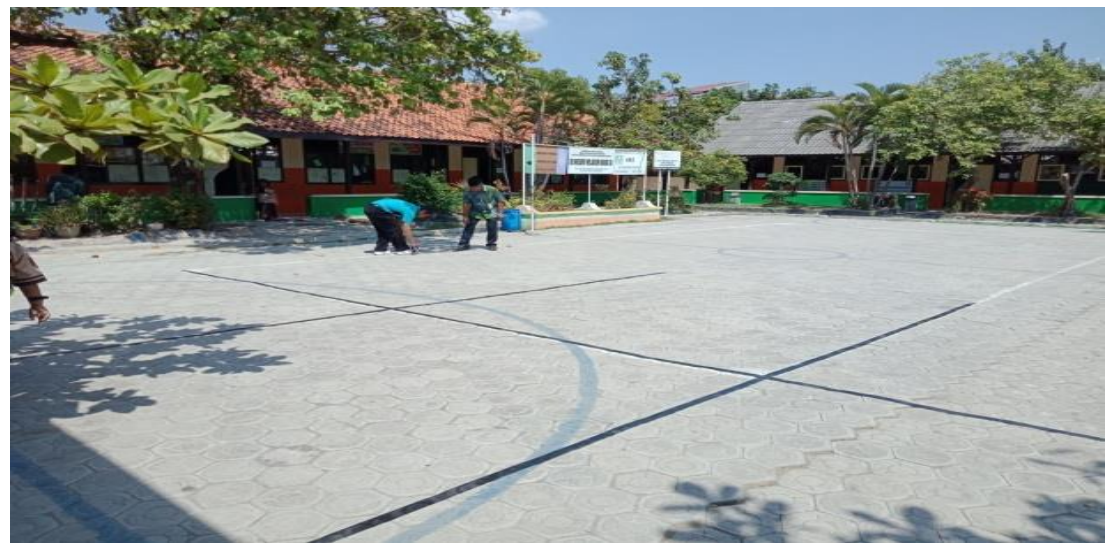

Figure 1. The process of making the Gopag Sodor court

Figure 1 shows the Gopag Sodor court made in the schoolyard by sticking adhesive tape on the floor as lines to form rectangular shapes. Usually, this game is done by children in the village. They use water to make the court. The water is poured onto the soil as lines to form rectangular shapes. Because the school does not have a soil yard, adhesive tape which is stuck on the floor is a solution to replace water. Usually, this game is played using a $9 \times 4$ meter rectangular court which is divided into six sections. Team members who get a turn to keep the court are divided into two, keeping horizontal lines and vertical line. Usually, one who keeps the front line is the student who has the biggest body. This is done to scare the opposing group. This is a strategy that is carried out by each team during the game. Before starting to play, students are given direction and the opportunity to discuss team strategy and preparation. According to Rukiyati, the character value of cooperation can foster a level of self-confidence, with the hope that students can easily adapt to new environments [11].

The adaptation process is needed by students wherever they are so that they can live according to the values and norms that apply in society. Living according to values and norms in society is not an easy thing, one must learn them first. Society often demands that we learn quickly to understand the rules. Character education can be stated as an activity that is deliberately created to form a generation with superior character, not only producing students with high cognitive abilities but also having characters that are capable of realizing success through positive student behaviour [12]. This emotional ability must be trained from an early age, both in the family environment and in the school environment. Children must be controlled in their daily use of gadgets because one of the negative impacts of using gadgets for children's development is that it is difficult to concentrate on the real world. Addiction to gadgets will make children easily bored, anxious, and angry when they are separated from their favourite gadgets [13].

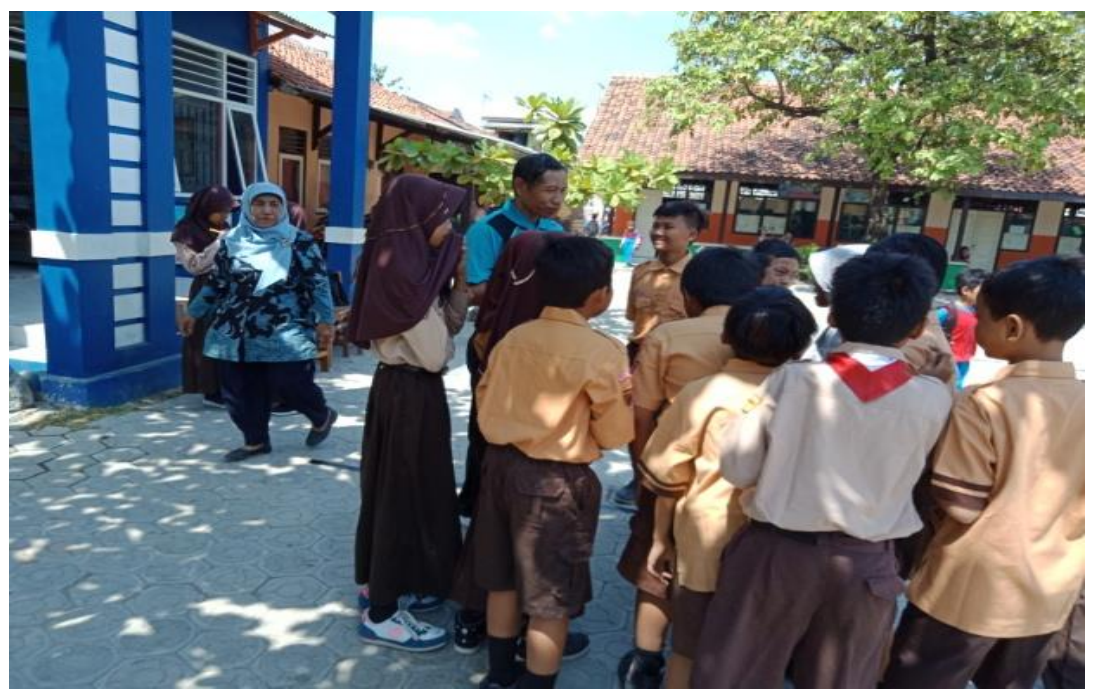

Figure 2. Briefing regarding the rules of the Gopag Sodor game

In Figure 2, a teacher is explaining the rules of the game. This aims to make students able to play sportively. The team members keeping on the horizontal line must try to block the opponent from crossing the line. The member guarding the vertical line has access to the entire vertical line located in the middle of the court. The opposing team must try to reach the very backline. Then the opponent must go back through the guard to get to the starting line. 
The team which guard the line must try to touch the opponent, but touching clothes, hats or shoes is not allowed. The touching is considered to be valid if they touch the body, hands or feet. To prevent such an incident, the teacher advised that the clothes should not become obstacles for students while running across the lines. This process can develop students' psychomotor abilities. Today's students rarely move hard for a long time because their activities are mostly in front of a computer screen. When schools hold activities in the field in the form of competitions, students are very happy and excited, because they know it is very useful for self-development. This is in line with the research findings of Furkan which states that academic and non-academic achievements are very helpful to motivate the student and school learning [14]. The better the academic implementation and the more activities that are followed, the fewer negative actions and thoughts of students appear because students always have activities. SMA Negeri 1 Dompu provides the widest possible opportunity for students and teachers to excel in various competitions by providing moral and material support so that students and teachers participate enthusiastically.

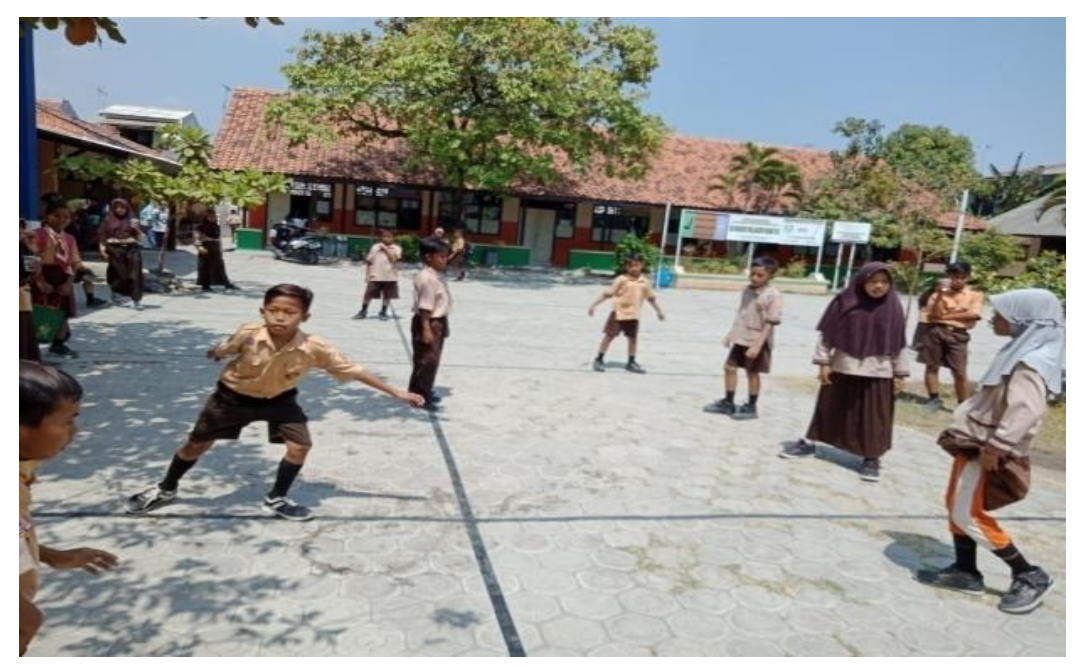

Figure 3. The process of implementing the Gopag Sodor game

In Figure 3, you can see the students playing Gopag Sodor. This game is carried out in groups consisting of men and women. They work together so that their team can win or beat other teams. In this game, they are also trained to develop team strategies that require cohesiveness. This cohesiveness is expected to be able to bring students to the community and also be implemented in the classroom with their friends. While teaching, teachers usually try to build the character of students through personal communication with students and create a pleasant classroom atmosphere. Character building integration in core activities of teaching and learning process includes teachers guidance by integrating character building; students assignment with character values; two-way communication between teachers and students teachers maintaining conducive situation with character values [15].

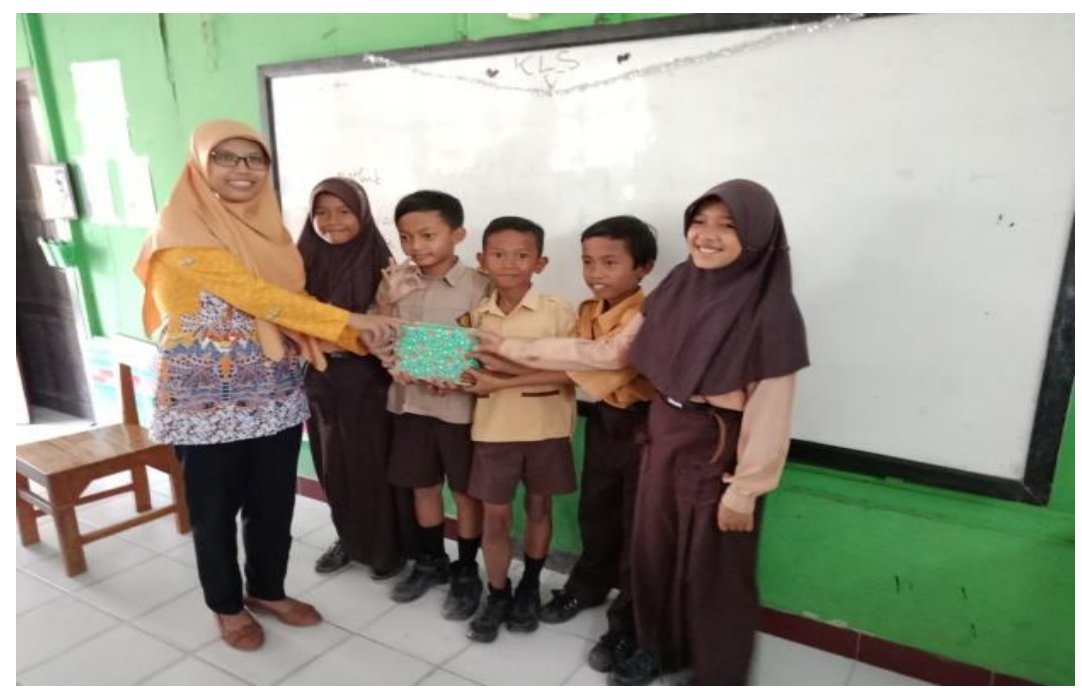

Figure 4. Giving reward to students who win the game of Gopag Sodor

Giving rewards to students who win and practice sportive cooperation while playing Gopag Sodor was done to 
make them happy and more excited again. This was also done so that other students could be motivated to do even better. Their sense of togetherness was strong. They worked together to get through every challenge given by the opponent. Before starting the game, they first gathered on the sidelines to discuss how to face the opponent. They also distribute tasks to all team members.

\section{Obstacles faced in Instilling Character Values of Cooperation}

According to Anggraeni, character values formed through school culture are religious values, discipline, responsibility, independence, creativity, environmental care, social care, honesty, hard work and love to read. Instilling character values in students is not as easy as imagined[16]. The obstacles were lack of support from parents, school facilities and infrastructure, and student's physical condition.

Parents have an important role in the development of children, but sometimes they leave it completely to the school or in this case the teacher. When children are at home, they get less attention from their parents. For parents, the important thing is that the child is silent and obedient. They don't want to be disturbed with children's matters because they are tired of working in the office. The solution given by parents is to provide cellphone and internet facilities. Unattended use leaves them free to access whatever they like. It can damage their growth. They will grow into individuals with low social sensitivity and tend to be individualistic. Every day children' life seems to be on a cellphone so that when they don't access the cellphone for an hour, they feel like something is missing. Parents should be able to be the ones who care most about their children for all the impacts of the changing era, but this is not the case.

According to Tannir, parents are not only obliged to meet children's needs, but also pay attention to their development, both physical and spiritual development [17]. Children's needs must be adjusted to their age level. Spoiling children for what they want is not the best solution, but it can damage their morale. Parents can fulfil children's requests by considering benefits. If what is asked for does not beneficial, it is better not to give it to the child. Elementary school children do not have mature thoughts, so when asking for something from their parents it seems pushy and without thinking. In this case, the role of parents is needed; they should care for their children's development and growth. The positive and negative impacts should be considered by parents. Children who get maximum guidance from parents will show different attitudes of students when compared to students who do not receive parental guidance. This is in line with Tannir's research (2013: 56). The findings revealed a slight difference between the experimental and control groups. Students who received character education showed slight progress in their self-esteem score, whereas students in the traditional instructional group did not show any progress in their self-esteem.

School facilities and infrastructure are important facilities. The implementation of the Gopag Sodor game requires a large soil field but SD Negeri Mejasem 03, Kramat District, Tegal Regency, does not have this facility. Its field is small and covered by paving block so that it is difficult to make Gopag Sodor court. Generally, if children are going to play this game, the field is formed in such a way as to use water that is splashed on the ground as a marker. The ideal situation cannot be pursued well. The thing that can be done is to replace water with adhesive tape as the lines of the court.

The physical condition of the students is one of the obstacles. The condition of students today is different from that of students before 2000. These differences include differences in character, mindset, independence and physical condition. The physical condition of children before 2000 tend to be stronger. It is very different from the condition of children today who are weak. This is influenced by food and lifestyle factors. Fast food is popular for students as their favourite food. They have poor sleep patterns. They access cellphone and computer excessively even though these devices emit radiation. In schools, teachers cannot force students to participate in activities that require extra energy, for example playing gobag sodor. If the child feels unwell, the teacher will ask students to rest or just watch on the sidelines. This is done to minimize the possibility of something bad happening.

\section{CONCLUSION}

Instilling character values in students through traditional games is not an easy thing to do. There are also many obstacles faced. This requires collaboration from various parties, including teachers, students and parents. This process must be carried out continuously so that the expected behaviour changes can be seen. 


\section{REFERENCES}

[1] Murtako, M. 2015. Culture-Based Character Education in Modernity Era. TA'DIB Journal. 20 (1) : 149-164.

[2] Syah, D. (2014). Factors Influencing the Achievement of Teachers of Islam Religion Education in Elementary Schools at Depok, West Java, Indonesia. International Education Studies, 7(10), 100-111

[3] Fanani, M. Z. 2013. Penanaman nilai Karakter Melalui Budaya Sekolah. Jurnal Al Hikmah. 3 (2); 297-312.

[4] Kinkopf, T. W and Casey, C. 2016. Character Education: Teachers' Perceptions of its Implementation in the Classroom. Delta Journal of Education. 6 (1)

[5] Satori, D., \& Komariah, A. 2017. Metodologi Penelitian Kualitatif. Bandung: C.V Alfabeta.

[6] Sugiyono. 2016. Metode Penelitian Kombinasi (Mixed Methods). Bandung: Alfabeta.

[7] Moleong, L. 2017. Metodologi Penelitian Kualitatif. Bandung : PT Remaja Rosdakarya.

[8] Miles, M. and Huberman, M. 2007. Analisis data kualitatif. Jakarta Universitas Indonesia Press.

[9] Safitri, D. D. (2018). Managing school based on character building in the context of religious school culture (Case in Indonesia). Journal of Social Studies Education Research, 9(4), 274-294.

[10] Novianti, N. 2017. Teaching Character Education to College Students Using Bildungsromans. International Journal of Instruction. 10 (4): 255-275.

[11] Rukiyati. 2014. Penanaman Nilai tanggungjawab dan Kerjasama Terintegrasi dalam perkuliahan Ilmu Pendidikan. Jurnal Pendidikan. IV (2).

[12] Supanji, R. W. 2013. Pendidikan Karakter Membentuk Insan yang Unggul. Jurnal Pendidikan Karakter. III (2).

[13] Hastuti. 2012. Psikologi Perkembangan Anak. Yogyakarta: Tugu Publisher.

[14] Furkan, N. 2014. The Implentation of Character Education through the School Culture in Sma Negeri 1 Dompu and Sma Negeri Kilo Dompu Regency. Journal of Literature, Languages and Linguistics. 3 : 14-44

[15] Marini, A. 2017. Character Building Through Teaching Learning Process: Lesson In Indonesia. International Journal of Sciences and Research. 73 (5): 176-182.

[16] Anggraeni, M. S. A. 2017. Implementasi Pendidikan Karakter Melalui Budaya Sekolah di SD Negeri Kotagede 3 Yogyakarta Tahun Ajaran 2016/2017. Jurnal Pendidikan Ke-SD-an. 3 (3); 151-158.

[17] Tannir, A. 2013. Effects of character education on the self-esteem of intellectually able and less able elementary students in Kuwait. International Journal of Special Education. 28 (1): 47-59.

\section{http://jurnalnasional.ump/index.php/dinamika}

